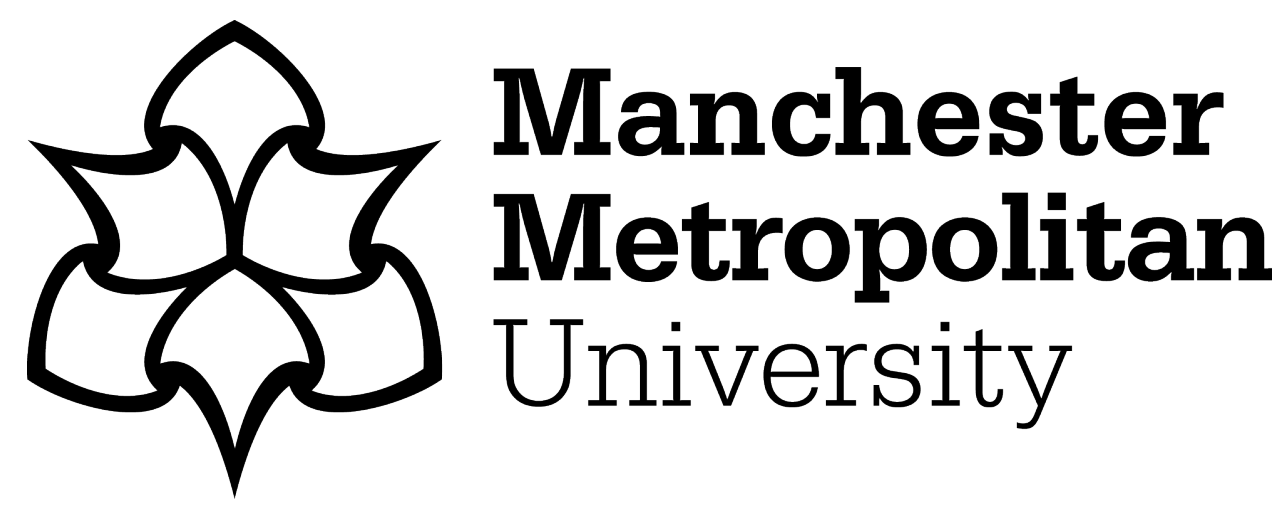

Bianchi, Raoul V and de Man, Frans (2020) Tourism, inclusive growth and decent work: a political economy critique. Journal of Sustainable Tourism, 29 (2-3). pp. 353-371. ISSN 0966-9582

Downloaded from: https://e-space.mmu.ac.uk/628296/

Version: Accepted Version

Publisher: Informa UK Limited

DOI: https://doi.org/10.1080/09669582.2020.1730862

Usage rights: Creative Commons: Attribution-Noncommercial 4.0

Please cite the published version 


\title{
Tourism, inclusive growth and decent work: a political economy critique
}

\author{
Raoul V. Bianchi \& Frans de Man ${ }^{1}$ \\ (2020) Tourism, inclusive growth and decent work: a political economy critique, Journal of \\ Sustainable Tourism, DOI: 10.1080/09669582.2020.1730862
}

\begin{abstract}
This paper interrogates the ideas of 'sustained' and 'inclusive' growth that are intrinsic to one of three UN Sustainable Development Goals (SDG 8 - Decent Work and Growth) adopted by the UN World Tourism Organisation's (UNWTO) 2030 sustainable tourism agenda. It provides a Marxian-inspired political economy critique of the UNWTO's embrace of SDG8 and highlights the blind spot within the UNWTO's inclusive growth-led SDG agenda with respect to questions of equity and social justice. The paper contends that the UNWTO's SDG-led agenda is contradicted by the logics of growth, competitiveness and profit-making that drive the continued expansion and development of tourism. Rather than addressing the structural injustices that entrench inequalities and reproduce exploitative labour practices, the notion of sustained and inclusive growth reinforces the primacy of capital and market notions of justice and continues to perpetuate a growth driven tourism development model. The paper contributes to a critical theorization of sustainable tourism and offers an informed critique of the current political agenda for sustainable tourism and its potential outcomes.
\end{abstract}

Keywords: political economy, sustainable tourism, inclusive growth, decent work. 


\section{Introduction}

Despite the innumerable policies and strategies devoted to advancing sustainable development agreed since the 1992 Rio Earth Summit a systemic paradigm shift towards sustainable tourism development remains hindered by the existence of "defence and delaying mechanisms in the economic and political system" (Müller, 1994, p.134). The launch of the UNWTO's sustainable tourism development agenda in 2015, framed by the United Nations Agenda 2030 and associated 17 Sustainable Development Goals (SDGs) seemed to "indicate the need to rethink the current economic growth ideology in the context of social and environmental needs in development" (Saarinen, 2018, p.33). Its advocates argue that it signals a major step towards building a global, integrated multi-stakeholder framework for ending extreme poverty, fighting inequality and injustice, and combatting climate change. Meanwhile however, growth-led, extractive, profit-driven economics continues to exacerbate an inter-connected global environmental, climate and development crisis (Klein, 2015).

The UNWTO and its partners contend that the managed growth of tourism can help engineer a transition to a "green economy" and contribute to "decent work creation, poverty alleviation, improved efficiency in resource use and reduced environmental degradation" (Stroebel, 2015: 2226). This paper presents an analysis and critique of the UNWTO's embrace and application of the SDGs with an explicit focus on SDG 8 (Decent Work and Growth) namely, the UNWTO's desire to harness tourism in order to "promote inclusive and sustainable economic growth" and "full and productive employment and decent work for all" (UNWTO, 2016, p. 33). Specifically, it addresses the neglect of work and labour in the tourism sustainability debate (see Baum et al., 2016), with due regard to the lack of attention to the critique of political economy in the UNWTO's SDG agenda (Hall, 2019, p.7).

This paper argues that the UNWTO's failure to address, much less challenge, the systemic processes of accumulation and exploitation that shape and constitute the competitive dynamics and industrial structures of tourism capitalism (Bianchi, 2018), undermines its ability to put forward a genuinely fair and progressive sustainable tourism agenda centred on concerns of environmental and social justice. It contends that earlier critiques of capitalist tourism development in the Global South, in which principles of economic justice and solidarity between nations were foregrounded (e.g., Shivji, 1973; WTO, 1980), have largely been superseded by market-friendly notions of 'sustained' and 'inclusive' growth that offer little by way of a challenge to the accelerated monetisation of nature and dehumanisation of labour. The injustices of enclosure and dispossession are furthermore often obscured by 
normative global sustainability discourses in which conservation rather than the just and equitable use and control of resources is foregrounded (Banarjee, 2003).

The argument put forward in the paper is premised upon the historical materialist methodology drawn from Marxist political economy (e.g., Marx, 1973, pp.100-108; Marx 1977). A materialist approach interprets capitalism as an historically specific, dynamic and contradictory mode of production driven by the pursuit of profit and the accumulation of capital which further intensifies the competitive dynamics of capitalist growth (Marx, 1974, p.555). Here, capital does not refer to simply the existence of commerce and markets, rather, it is a system with a distinctive set of logics that can only be understood "in the context of a particular social relation between appropriator and producer” (Wood, 2016, p. 24). The historical-geographical reproduction of capitalist social relations is played out through the continuous separation of humans from their means of production in tandem with the social reproduction of workers via the (unpaid) household labour of women (usually) and the wider relations of solidarity and mutual exchange that sustain the social fabric of communities (De Angelis, 2007, p. 37). A third component of capitalist expansion enabling the continuous production of a labour force is constituted via the enclosure and appropriation of natural assets and dispossessing once self-sustaining inhabitants of their independent means of obtaining a livelihood. The $16^{\text {th }}$ and $17^{\text {th }}$ century English acts of enclosure which drove peasants off their land and extinguished customary use rights as well as the processes of settler colonialism witnessed in the US, both of which gave rise to capitalist property relations, represent similar logics of appropriation and dispossession (see XXX in this issue), which have played out in various ways in colonial and imperial histories worldwide (see Wolf, 1982).

The resultant antagonism between capital and labour arises out of the exploitative nature of capitalist production and more specifically, the treatment of human labour as a factor of production (Selwyn, 2015, pp. 516). Systemic forces of injustice arise out of the commodification of human labour power and the enclosure of natural wealth and resources necessary to sustain human livelihoods, but which are also integral to the expansion of capital and endless growth upon which it depends (Hickel, 2019a). Challenges to the normal' orderly workings of the market and the attendant 'need' to ensure an adequate return to capital are characteristically viewed as 'disruptive' and contrary to the "formal justice of the market" (Streeck, 2014, pp. 60-61). 
Section one identifies the logics of growth, process of capital accumulation and role of labour in the tourism political economy as the basis for the analysis and critique of sustainable tourism development as construed by the UNWTO. The paper then interrogates the UNWTO's SDG agenda in the context of the historical-political struggle of the UNWTO to define, develop and lead a global sustainable tourism agenda since 1992. This section draws on an analysis of key UNWTO reports ${ }^{2}$ to interrogate the ideological and linguistic framing that shapes the UNWTO's engagement with SDG 8 together with the personal involvement of the second author of this paper. As director of the Retour Foundation he was a core member of Tourism European Network (TEN) and the Transforming Tourism Initiative both of which have lobbied the UNWTO for greater civil society representation in relation to discussion and elaboration of the Global Code of Ethics for Tourism (WTO, 1999b), the Framework Convention on Ethics (UNWTO, 2017b) and the UNWTO's SDG agenda. Between 1999 and 2002 he was the elected Northern co-chair of the tourism caucus of the CSD-NGO steering committee, the official civil society partner of the United Nations Commission on Sustainable Development (UNCSD) from its $7^{\text {th }}$ meeting in 1999 (UNCSD7), when tourism was introduced into the UN sustainable development agenda, until the 2002 World Ecotourism Summit. It was at this point that the UNWTO brought the officially sanctioned NGO involvement to an end as a result of growing disagreement over the content and direction of UNWTO policy. Following this NGO participation became increasingly ad hoc and sanctioned only at the UNWTO's discretion. The final section contributes to a political economy critique of the principles of 'sustained' and 'inclusive' growth that are integral to the UNWTO's global sustainable tourism development agenda.

\section{The political economy of sustainable tourism}

Scholarly attention in sustainable tourism has moved away from a conservationist resource management focus towards diverse and rigorous theoretical inspection of concerns related to inter alia, destination governance (Bramwell, 2011; Dredge and Jamal, 2013) sustainable livelihoods (Tao and Wall, 2009), poverty reduction (Neto, 2003; Scheyvens, 2007), empowerment and social justice (Jamal and Camargo, 2014; Coria and Calfucura, 2012; Scheyvens, 1999), environmental ethics (Holden, 2003), the tourism commons (Briassoulis, 2002), and increasingly, degrowth (Hall, 2009; 2010; Higgins-Desbiolles et al., 2019). And yet studies of tourism's complex relationship to sustainability and the forces of economic development are typically reliant upon static and descriptive conceptions of political 
economy in which tourism capitalism is construed as the aggregate of commercial tourism activities or "set of assets" (Sharpley, 2015, p.448), rather than one driven by the competitive struggle between capitals, the exploitation of labour and the energy-intensive use and commodification of nature. ${ }^{3}$ Contradictory capital/labour relationships are neither static nor universal (Burnham, 1994). Rather they are shaped by the daily struggle of labouring classes to defend their standards of living (including, resistance to enclosure of the resources and eco-systems upon which such livelihoods depend) and the right of capital to organize the labour process in accordance with the imperatives of profit-making (Selwyn, 2015). The precise social coordinates of struggle are nevertheless shaped by geographic variances of capitalist development and local social structures together with the collective capacity of labouring classes to organise and resist exploitation (Chibber, 2013).

The growing consensus surrounding the imperative of sustainability in tourism that permeate policy and corporate pronouncements conceals unresolved contradictions between sustaining tourism and sustainable development (Higgins-Desbiolles, 2018; McCool et al., 2001). At the heart of this protracted debate lies a tension between "weak" and "strong" interpretations of sustainability (Hunter, 1997, pp.853-4). The former is "industriallyoriented" and tends towards an adaptive stance, permitting a managed and regulated expansion of tourism, while the latter advocates stricter "limits to growth" and constraints on the depletion of natural capital (see Saarinen, 2006, pp.1126-1129). This apparent dichotomy nevertheless avoids a more fundamental interrogation of the meaning of sustainable development in the light of the forces making for the relentless growth of tourism and the conditions under which value is created and surpluses appropriated.

The political ecology of tourism employs a similar conceptual armoury to examine the struggle between different actors and institutions over access to and use of environmental resources for tourism (Bramwell, 2015: 211). Such conflicts are evident in Cole's (2012) work on tourism and water in Bali as well in recent analyses of the intersections between the restructuring of tourism capitalism, territorial planning and socio-environmental struggles in the Balearic Islands (Blázquez et al., 2015; Hof and Blázquez, 2015). Governance perspectives examined the struggle between different state actors to define and advance the adoption of policies and planning mechanisms for sustainable tourism (Bramwell, 2011). Advocates of tourism degrowth have argued have that to redesign and align tourism economies with sustainability requires a more profound challenge to the current model of growth-led tourism that goes beyond simply managing and/or balancing the growth of 
tourism with resource management and conservation (Hall, 2009; Higgins-Desbiolles et al. 2019). However, with notable exceptions (see Büscher and Fletcher 2017; Duffy 2015; Fletcher 2011), the analysis and critique of the complex and contradictory relationship between tourism, capitalist development and sustainability remains divorced from more searching and systematic analyses of its political economy much less the class dynamics of capital-labour relations in the struggle to define and implement sustainable tourism.

\section{Tourism development and growth}

The period between 1990 and 2008 witnessed 260 per cent growth in international tourist arrivals and the consolidation of tourism as major category of international trade, with the fastest growth in arrivals taking place between 2003 and 2007 (UNCTAD, 2010: 2). Largely unperturbed by the 2008 financial crisis, by 2018 growth in international tourism had reached 6 per cent per annum, exceeding the average rate of global economic growth (3.7 per cent) (UNWTO, 2019). During the same year international tourism accounted for 10.4 per cent of global output with an estimated total economic value of US\$8.3 trillion (WTTC, 2018). Meanwhile, since 1990 the number of people living on less than US\$5 a day increased by more than 370 million while global GDP per capita simultaneously grew by 65 per cent (Hickel, 2017, p.56). Despite the emergence of increasingly diverse measures of human well-being and measures to account for externalities since the OECD first mandated the pursuit of GDP growth as the priority of government in the 1960s, it remains the principal strategy of governments and international development agencies for delivering prosperity (Raworth, 2018, p.38). Indeed, the SDGs themselves proscribe growth rates of 7 per cent per year as the principal means of eliminating extreme poverty in 'developing' countries.

Bramwell and Lane (1993, p.2) argued that sustainable tourism is not "anti-growth" but rather is linked to the need, identified in the 1987 Brundtland Report (WCED, 1987), to bring about "fairness" and "convergence" between rich and poor nations in the global trading system. Notwithstanding the variants of capitalist development worldwide, since its adoption as a major plank of economic development by newly-independent 'Third World' states commencing in the 1950s tourism has been construed as an ideologically-neutral, technical enterprise whose success or failure is predominantly judged in terms of annual increases in arrivals and tourist receipts and their contribution to GDP-led economic growth (UNCTAD, 1973, 2010). 
During the 1960s and early 1970s when environmentalists began to highlight tensions between economic growth and the environment, tourism seemed to offer 'developing' countries a viable alternative to becoming suppliers of raw materials and agricultural commodities to the industrialized West, with the potential to help transform them into modern industrialized economies (Peters, 1969). Since then much has been made of the contribution of tourism-led growth to economic development (WTTC, 2018), including the claim that market-driven tourism has functioned as an engine of wealth redistribution from rich to poor countries (Keller and Bieger 2011, p.1).

While the view persists amongst international development agencies that tourism is uniquely placed to contribute to economic development and reduce poverty in the Global South (UN News, 2011), revenue leakages have continued to plague tourism development UNCTAD (2010, p.9). The UNWTO and other international institutions have recognized such shortcomings but remain committed to the logics of export-led tourism albeit one whose adverse consequences merely need to be better managed (Rifai, 2017). However, the very need to trade (in tourism) and the terms under which such trade is undertaken is "often a sign that an economy is unsustainable" (Douthwaite 1999, p.171). The contribution made by tourism to improvements in national income, living standards and poverty reduction ${ }^{4}$ often lack deeper interrogation of the social and political dynamics of tourism development. The imperative to earn a wage and the very fact that tourism may provide jobs for people who don't have many alternatives (see Steiner, 2006: 170), is indicative of the disempowerment of labouring classes and often coexists with exploitative labour regimes within destinations. Although many low-income states did experience a boost to national income and employment the development of tourism destinations often entailed the disruption of native economies and consequent emergence of socio-economic inequalities (Britton, 1980). Tourism investment and economic growth in recent years continues to accelerate land dispossessions, loss of selfreliance and the intensification of ecological destruction (Holden, 2013, pp.108-111), with little discernable decrease in inequalities (Alam \& Paramati, 2016).

The acceleration of global trade and consolidation of neoliberal market economics in the 1990s saw tourism emerge as a major avenue of capitalist development and pillar of economic growth strategies for advanced and emerging economies alike (Britton, 1991). In 1991 GNP was superseded by Gross Domestic Product (GDP) as the principal benchmark against which the economic strength and wealth of nations would be measured (Fioramonti, 2013, pp.41). This seemingly innocuous change attributes income generated by foreign- 
owned firms to the countries in which they were generated and not the country in which the firm is headquartered. This gives the misleading impression that national incomes are growing and the conditions of development improving despite continuing economic privations and revenue leakage in the Global South (see Hickel, 2017). Not only does GDP shape the understanding of value, given the weighting of tourism in the export sectors of many low-income economies in which foreign-based transnational corporations and off-shore investors play a significant role, it potentially inflates the economic benefits provided by tourism (see FDI Intelligence, 2018). The question of value, how it is produced and by whom it is appropriated in tourism economies, is therefore a critical one for the evaluation of any sustainable tourism development agenda.

\section{Tourism capitalism and the creation of value}

Tourism development catalyses new forms of value and reshuffles the internal distribution of capital, land use and organisation of labour as they become structured around the demands of tourism capital accumulation. The industrial organisation and concentration of tourism industries emerges from the interaction between the degree and scope of integration of domestic economies into global markets, firm strategies and the character of state intervention in a given destination (Clancy, 2001, 26-27). Considerable corporate concentration exists in the various tourism sub-sectors and increasingly amongst online digital platforms (Gössling \& Hall, 2019, p.12). Destinations however often comprise a multitude of different firms of varying scale operating across a spectrum of "capitalist and non-capitalist and formal and informal sectors" (Gibson, 2009, p.529). Nevertheless, local firms in the Global South are often subordinate to lead tourism firms based in the advanced capitalist countries, who are able to monopolise revenues through their governance of global commodity chains (Christian, 2016; Mosedale, 2006).

Given the difficulty of exerting "property rights over tourism experiences" (Williams, 2004, p.62), competition between diverse constellations of tourism enterprise over access to and use of resources fuels the relentless privatization and commodification of lands, ecosystems and labour in continuous cycles of "destructive creation" (Büscher and Fletcher, 2017). In the absence of robust mechanisms for reconciling competing uses, tourism may precipitate the enclosure and exploitation of "common pool resources" (Briassoulis, 2002), to make way for the construction of resort infrastructures and privatized tourism activities. The 
very destruction of customary livelihoods and monetization of these habitats often results in the expansion of wage-labour upon which such growth in fact relies (Mittal and Fraser, 2018). Tourism economies are also often vulnerable to unproductive 'rent seeking' and speculative real estate investment as means of sustaining profitability and capital accumulation, such as fuelled the frenzy of real estate-led tourism growth along the Spanish littoral from the 1990s until the 2008 financial crash (Murray et al., 2017; Hof and BlázquezSalom, 2015). ${ }^{5}$

Financialization has fuelled growth in mergers and acquisitions in the global tourism and hotel sectors which is increasingly augmented by the entrance of private equity and 'real estate investment trusts' (REITs) in the purchase of major tour operations, hotel and resort assets (ILO, 2010, pp.29-32; Yrigoy, 2016). The resultant complexity of corporate ownership and financial flows in tourism has been further magnified by the rise of corporate on-line travel agencies (OTAs) and online rental platforms, leading to the disruption of existing patterns of corporate dominance in key tourism sub-sectors whilst exacerbating new patterns of online market concentration (Gossling and Hall, 2019). ${ }^{6}$ Despite their ability to unlock value in idle assets, the rise of online rental platforms creates additional challenges for achieving 'decent work' in many areas of tourism and hospitality (Dredge \& Gyimóthy, 2015). Evidence nevertheless does exist for the emergence of alternative business models and distinctive modes of value creation in tourism (Cave and Dredge, 2018). However, the potential for collaborative and non-monetary forms of value creation presented by digital platforms are small-scale and thus far present little threat to the dominance of corporate and financialized systems of capital accumulation that drive tourism growth.

\section{Tourism and labour: the hidden dimension of sustainability}

Given the prevalence of low pay, exploitation and weak protections across the tourism and hospitality industries (Cañada 2014; ILO 2010, 2017; Teberga De Paula, 2018), it is unsurprising to find that 'decent work' (SDG 8) is integral to the UNWTO's SDG agenda (UNWTO, 2017). Studies of sustainable tourism are rarely accompanied by an examination of the intersecting axes of exploitation and discrimination arising out of the class character of tourism capitalist development and attendant patterns of resource use and appropriation. Despite a substantial literature on employment practices and working conditions consideration of the systemic nature of labour exploitation in tourism capital accumulation 
has been overshadowed by orthodox managerial and economic perspectives (Ladkin, 2011). Critical engagement with SDG 8 from the perspective of dignity in tourism employment also construes the tourism workforce as a factor of production, disregarding the class relations of struggle that underpins exploitative labour regimes (Winchenbach et al., 2019).

Tourism industries are marked by "diverse labour market tensions, varied subsistence strategies, and complex dynamics of power relations" (Madsen Camacho, 1996, p.33). These are shaped as much by a nation's overall political economy (Williams 2004, p.66), as they are the "hybrid and contradictory economic formations" of tourism capitalism (Gibson, 2009, p.530). The myriad small-scale entrepreneurs that underpin tourism economies are also often exposed to precarity and chronic insecurity resulting from market volatility, seasonality and unfavourable regulatory regimes (see Jamal, 2019: 43-45). That said, it is those at the lower ends of the labour market with little more than their labour or "free floating" capital to sell (Crick, 1994, p.163), who are most exposed to the insecurities and injustices of tourism work.

The political economy of global tourism and associated regimes of accumulation is produced and reproduced at different spatial scales partly through the ability to draw on a vast pool of globalised and socio-ethnically-differentiated labour amongst whom ethnic minorities, women and migrant workers are disproportionately represented (Chin, 2008; Chok, 2009; ILO 2012). Hence, the divisions of labour within large, transnational firms (particularly in global cruise companies, large-scale resorts and hotel chains) are often structured according to ethnicity, nationality and gender (Chin, 2008; Hampton, 2010; Wood, 2000). Moreover, despite the growing popularity and high yields associated with specialist 'niche' tourisms systemic labour precarity and poverty is widespread (see Hampton, Jeyacheya \& Lee, 2018). Ample evidence also exists pointing to a correlation between the construction of luxury tourism installations and exploitative working conditions, including in all-inclusive resorts in the Seychelles (Lee et al., 2015), luxury hotels in Pakistan (Sheikh, 2010) and integrated mega-resorts in South-East Asia (Chok, 2009; Hampton 2010).

Collective bargaining in the tourism and hospitality sectors is undermined by weak trade union representation as well as the fragmented and geographically dispersed structure of tourism producers. Notwithstanding strong labour unions in key support services (e.g. air traffic control), the fragmentation of tourism divisions of labour and perishability of tourist services themselves constrains the ability of labour to slow down the speed of production or disrupt supply-chains. The complexity of globalised corporate ownership structures has 
enabled the out-sourcing and sub-contracting of work to employment agencies undermining collective bargaining and eroding employee protections (Grossman and Greenfield, 2006; Sheikh, 2010).

While low-skilled poorly paid tourism-hospitality sector jobs may be preferable to the arduous nature of work in other export sectors or traditional agrarian/fishing occupations, this does not negate its frequently exploitative nature. As attested by the prevalence of precarious conditions amongst tourism workers in the Global South 'decent work' in tourism can be hard to find (Lee et al., 2015, p.198). The fact that foreign-owned tourism corporations may pay higher wages than many small-scale locally owned firms or that wages may rise in line with growth and profits does not negate the need to interrogate the political-economic conditions under which surpluses are produced and distributed.

\section{The UNWTO and sustainable tourism}

The Brundtland Report (WCED, 1987), is commonly regarded as the launch pad for global political action to achieve sustainable development. ${ }^{7}$ Although it fell short of mapping out an agenda for radical political reform it explicitly recognised the relationship between the "short-sighted" pursuit of prosperity, overuse of environmental resources and, poverty (WCED, 1987, p.27). However, the emphasis on continued growth as means of relieving poverty meant that tensions remain between economic growth and the equitable distribution of "life-sustaining resources and opportunities" (Goldman, 2011. p.2).

Agenda 21, a template for practical action on sustainable development agreed at the Rio 'Earth Summit' in 1992, sought to address questions of equity through encouragement of civil society involvement in the design and implementation of a global sustainable development agenda. Somewhat paradoxically, trade liberalization across all economic sectors was endorsed as means of stimulating sustainable economic growth (UN, 1992). Meanwhile, proposals to set up a centre to monitor corporate malpractice and references to over-consumption in the industrialized countries were deleted from the draft convention as a result of lobbying by leading industrial nations (see Hilary, 2013, pp.61-63).

During the period from 1992 until the 2012 Rio+20 Earth Summit in Johannesburg the United Nations Commission on Sustainable Development (UNCSD) coordinated a series of annual multi-stakeholder meetings with representatives of civil society and other 'major 
groups (labour unions, local governments, local communities and industry bodies etc.) in an attempt to forge a consensus around key issues and challenges for sustainable development and identify ways for governments to address these. In the lead up to the UNCSD-7 in 1999 NGOs involved in campaigning on tourism-related issues were invited to communicate a common position on sustainable tourism that respected the divergent stances of Northern and Southern NGOs (CSD, 1999a).

Although the WTO provided some input into the UNCSD (see WTO, 1999a), at this stage it was unable to take a leading role at the UNCSD-7 meeting due to being neither an industry body nor an NGO. While differences emerged over the Industry-specific Agenda 21, supported by the World Travel and Tourism Council (WTTC) ${ }^{8}$ and the International Hotel and Restaurant Association (IHRA), versus Local Agenda 21 (a joint initiative of UNEP and ICLEI (Local Governments for Sustainability) ${ }^{9}$ and supported by the NGO Tourism Caucus and Local Authorities, the WTO refrained from taking a firm position.

The multi-stakeholder dialogue on tourism at the UNCSD-7 in 1999 marked the zenith of NGO and civil society participation following the Rio summit (Dodds, 2019). It also marked a move away from the WTO's earlier commitment to a social vision of tourism development set out in the Manila Declaration (WTO, 1980) and Acapulco Document (WTO, 1982) towards an unequivocal commitment to neoliberal market-led principles (see HigginsDesbiolles, 2006). Tensions between the NGO Tourism Caucus and WTO over the neoliberal direction of its sustainability agenda at the World Ecotourism Summit in 2002, resulted in a permanent rift, marking the end of formal NGO participation in the high-level agenda setting framework. This signaled a major turning point for the WTO's engagement with an emerging global agenda for sustainable tourism. Hitherto, the WTO had been primarily concerned with the promotion of tourism as an instrument of economic development. In its report to UNCSD-7 the WTO (1990a, p.5) states that "market forces alone do not guarantee that tourism will be sustainable". This is then somewhat contradicted in the Global Code of Ethics for Tourism in which tourism is directly addressed as a "factor of sustainable development" (Article 3) but within the framework of a "market economy, private enterprise and free trade" (WTO, 1999b). The UNWTO's reinforced its commitment to trade liberalization in tourism services following World Trade talks in Doha (2001) and Cancún (2003), by which time it had become a specialized agency of the UN (Ferguson, 2007). 


\section{The UNWTO and the Sustainable Development Goals: SDG 8}

The United Nations 2030 Agenda for Sustainable Development is the basis of UNWTO's attempt to establish a common framework of action centred on sustainable tourism. The SDGs represent a compromise negotiated and agreed between governments, the implementation of which falls to major industry associations and multi-stakeholder groups representing different sectors, in which corporate influence is significant (see Gleckman, 2016). Of the five over-arching sustainable development goals set out in the preamble of Agenda $2030^{10}$ economic growth is not in fact addressed as an explicit goal (UN, 2015). However, the proclaimed necessity of growth is clearly stated in SDG 8 with the resolve to: "create conditions for sustainable, inclusive and sustained economic growth, shared prosperity and decent work for all" (https://sustainabledevelopment.un.org/sdg8). Here growth is reframed as an explicit goal of sustainable development, not just a means to achieving it, although no specific rationale is given for doing so other than the taken-forgranted assumption that growth and productivity improvements are essential for driving progress towards implementing the SDGs.

While the SDGs are construed as "integrated and indivisible" (UN, 2015), the UNWTO has chosen to focus specifically on SDG 8 with the aim to "Promote sustained, inclusive and sustainable economic growth, full and productive employment and decent work for all" along with SDGs 12 and 14 (UNWTO, 2017a, p.99). Tourism is explicitly addressed in Target 8.9: "to devise and implement policies to promote sustainable tourism that creates jobs and promotes local culture and products" (UNWTO, 2017a, p.99). This target is linked to two indicators:

- 8.9.1: Tourism direct GDP as a proportion of total GDP and in growth rate

- 8.9.2: Proportion of jobs in sustainable tourism industries out of total tourism jobs.

When charged by the UN to formulate measures for Indicators 8.9.1 and 8.9.2 by 2020, the UNWTO proposed to replace them with a single indicator (combing growth and decent work) entitled "Progress towards sustainable tourism" along with three additional submeasures "that provide a good (conceptually precise and feasible) indication of the three dimensions of sustainable tourism (economic, social and environmental)" (UNWTO, 2018a). Additionally, the UNWTO proposed that the economic dimension of sustainability be measured by tourism's contribution to GDP, using the UNWTO's Tourism Satellite Accounting methodology. By way of justification the UNWTO claims that "While Target 8.9 
has many parts, within the context of Goal 8 it is understood that its main focus is "promoting sustainable tourism" (UNWTO, 2018a, p.6). In addition to misrepresenting the parent goal, the relationship between growth and sustainable tourism remains unclear if not outright contradictory. The proposed measures themselves consist of little more than a restatement of growth-led economic orthodoxies through which tourism's contribution to economic development has been conventionally interpreted.

The prioritization of "sustained economic growth" demonstrates the degree to which the SDGs are framed by business-focused market principles in which the "priorities" of the corporate sector are often foregrounded (UNWTO, 2016, p.24). Constant reference is made to supporting and incentivizing the private sector and promoting a "pro-competitive and effective policy framework" in order to stimulate further growth (UNWTO, 2017a, p.19). Both the wider Agenda 2030 and UNWTO's interpretation express and consolidate the institutionalization of a "normative neoliberalism" through which markets and competition have become the defining principle of a single, global political-economic system (Davies, 2016, pp.127-129).

Agenda 2030 demonstrates the continued hold of this logic through its explicit support (SDG17.10) for "a universal, rules-based, open, non-discriminatory and equitable multilateral trading system under the World Trade Organization" (https://sustainabledevelopment.un.org/sdg17). The UNWTO (2017a, p.12) makes frequent reference to the need to "remove barriers to trade" with little evidence given to demonstrate how this enhances sustainable tourism development other than by virtue of tourism's potential to enable developing countries to "take part in the global economy" (UNWTO, 2017a, p.24). The Framework Convention on Tourism Ethics similarly encourages tourism multinationals to "promote local and sustainable consumption and production" and to avoid "excessive repatriation of their profits" in return for the "freedom to invest and trade" (UNWTO, 2017b, Art. 12.5, p.88). Nowhere is there any mention of intractable global inequalities of wealth and income (Hickel, 2017, pp.37-43), or the link between tourism growth, uneven distribution of wealth and excessive levels of consumption by a privileged minority of travellers.

\section{Sustainable tourism and decent work}

The idea of 'decent work' emerged in parallel to the broader debates on sustainability during the 1990s. In 1999 the International Labour Office defined decent work as "jobs of acceptable quality" and "respect for the fundamental rights of work" (ILO, 1999, pp.4-7). 
While such rights are seen as essential to enable workers to "claim a fair share of the wealth they have helped to generate" the ILO's definition remains framed by the contribution decent work could make to growth and the need to accommodate "business and employers concerns" (ILO, 1999, p.10). Decent work was subsequently incorporated into the MDGs and is now integral to UN Agenda 2030 as part of SDG 8, thanks in part to the persistent lobbying of the ILO itself.

The ILO's $(2017$, p.11) recent guidelines on decent work identify key challenges to be addressed in the areas of tourism and hospitality employment including, the high incidence of informal working arrangements, insecurity, poor working conditions, low wages, long working hours, high turnover rates, limited social protections and incidences of discrimination, exploitation and sexual harassment. It goes on to propose ways in which sustainable tourism policies could contribute to a decent work agenda related to Targets 8.9, 12.b and 14.7 (ILO, 2017, pp.15-16). However, despite acknowledging the need to strengthen labour protections, promoting social dialogue and the rights to collective bargaining the ILO's conception of decent work remains aligned with "enhancing tourism enterprise performance" and policies that promote increased "efficiency and productivity" (ILO, 2017, p.36, p.43). There is little engagement with the underlying causes of 'indecent' work much less an attempt to understand how increased productivity may in fact result from intensified forms of capitalist exploitation and integration into global markets.

The UNWTO has, in various declarations (WTO, 1980, 1999a, 2017), stressed that due attention be given to the rights of workers and the equitable distribution of wealth in tourism. In 2008 the UNWTO and ILO jointly agreed to support "dignified work" and advance the application of international labour standards but failed to identify an explicit programme of action to achieve this (Gascon, 2019). Despite the participation of trades unions in UNCSD-7 the systemic forces of labour exploitation in tourism remain unaddressed (CSD, 1999c). Much of the UNWTO's focus has been on developing statistical formulae for calculating tourism employment with little regard to develop more robust criteria for the evaluation of decent work. Not only does Indicator 8.9.2 reduce the interpretation of decent work merely to the "number of jobs in tourism industries as a proportion of total jobs and growth rate of jobs, by sex", the UNWTO dilutes the meaning of sustainable tourism even further by suggesting that the social dimension of tourism sustainability can be comprehensively assessed through measures of tourism employment (UNWTO, 2018a, p.5)

To reduce the evaluation of decent work to a simple calibration of the numbers employed in the tourism industries disregards the interplay between the organization of work 
in tourism economies and the class dynamics of capitalist labour relations (cf. Selwyn, 2014). The limited horizons of the UNWTO's interpretation of dignified and decent work is reflected in Target 8.7 which deals with the elimination of forced labour, modern slavery and human trafficking and securing the prohibition and elimination of the worst forms of child labour (UNWTO 2017a, p.99). As serious as these issues are, this construes decent work predominantly as a moral issue disregarding how such human rights abuses and exploitative labour regimes may be linked to the hollowing out of social protections as part of the 'normal' workings of tourism capitalism.

The UNWTO nevertheless recognizes that, “tourism's ability to bolster decent work is a complex issue" and acknowledges the challenges presented by the fragmented character of tourism labour regimes and conditions of work (UNWTO, 2018b, 55-56). However, the recent Framework Convention suggests that the protection of job security and social protection for workers can only be guaranteed "so far as possible" (UNWTO, 2017, p.87). This exempts the tourism industry from respecting universally acknowledged worker's rights by confining these within "the specific constraints linked in particular to the seasonality of their activity, the global dimension of their industries and the flexibility often required of them by the nature of their work" (UNWTO, 2017b: Art 12.1, 87). As if to further demonstrate the attenuated definition of decent work and its subordination to growth the current UNWTO Secretary-General failed to include decent work amongst the most pressing challenges facing the tourism industry (Fingar, 2018), while not one of the 21 recommendations in the Chengdu Declaration on Tourism and the SDGs address decent work (UNWTO, 2017c).

\section{Discussion and Critique}

The UNWTO's SDG agenda prioritizes the sustained growth of a 'green' tourism economy that will contribute to "economically viable and robust growth, decent work creation, poverty alleviation, improved efficiency in resource use and reduced environmental degradation" (Stroebel, 2015, p.2226). As if to reinforce the limited prospects for a genuine rethinking of the tourism political economy the notion of green growth has stimulated a "green gold rush" of foreign investment in "responsible" and "sustainable" tourism assets (Mitchell, 2017). Meanwhile global spending on 'ecotourism' - still largely associated with sustainability (UNWTO, 2017a, p.26) - outstrips aggregate investment in the industry (UNEP, \& UNWTO, 2012, p.viii). 
For the UNWTO "growth is not the enemy" (Rifai, 2017). Rather, the adverse consequences of tourism growth can be addressed through the sustainable management of growth and concomitant embrace of "more inclusive" and "sustainable" business models (UNWTO, 2017a: 12). As indicated by Target 8.4 it is expected that the negative externalities of tourism growth can be addressed through "decoupling" growth from ecologically unsustainable resource use (UNWTO, 2017a, 28). While there has been some evidence of the relative decoupling of growth from resource degradation between 1980 and 2002, the material footprint of growth has since accelerated (Hickel, 2019b, p.3). Moreover, claims that many rich nations have achieved lower carbon emissions despite higher GDP, ignores the degree to which emissions have been out-sourced through global supply chains or that aviation and shipping emissions are not included in calculations.

The UNWTO (2017a, p.27) makes explicit mention of the potential for "innovation and "new technologies" to stimulate new business models and "efficiency gain". There is however no mention of the associated costs in terms of unsustainable resource use, residential displacement and gentrification pressures brought about by the rise of digital rental platforms and the attendant concentration of corporate power in the so-called "sharing economy". As welcome as they are, proposals to account for the hidden costs or externalities produced by tourism (see Epler Wood, 2019), continue to construe nature as an "ecosystem service" (Sala, 2011), reducing the natural world and all its attendant complexity to merely another form of capital that is substitutable for another (Fioramonti, 2013, p.89).

The model of "inclusive green growth" espoused by the UNWTO (2017a, p.7) is rooted in the World Bank's paradigm of "inclusive growth" which calls for accelerated growth to reduce poverty (World Bank, 2009, p.1). The UNWTO (2017a, p.7) is also at pains to draw connections between the SDGs and "sustainable business operations that can spur competition and increase profit". There are numerous references to the "priorities" of the private sector, including those of the Spanish tourism sector (UNWTO, 2016, p.24). But there is little indication of the diverse capitals that have shaped the structure of Spanish tourism, much less acknowledgement of the damage to the environment and social fabric wrought by prioritizing the interests of real estate and construction capital that drives the growth of tourism (Murray Mas et al, 2017).

In its continued support for trade liberalization the UNWTO's SDG-led agenda envisages the further integration of small-scale producers in developing countries into global markets as 
a means of enhancing the competitiveness and export-led tourism growth (UNWTO, 2017a, p.24). Inclusiveness is envisaged in terms of facilitating access of producers to global markets and increasing employment opportunities for the poor without challenging existing hierarchies of wealth and power. There is no acknowledgement of how trade liberalization and increased foreign investment, the logic of which pervades inclusive growth discourses (Saad-Filho, 2009), may accentuate the flow of benefits to large private capital at the expense of such small-scale producers and workers (Schilcher, 2007).

Governed by liberal market pragmatism the UNWTO disregards the tenuous link between tourism growth and reduction of poverty and/or inequalities (see Hampton, Jeyacheya \& Long, 2018), as well as the threat to the livelihoods and resources of peasant and labouring classes entailed by the drive for the sustained growth of tourism (Devine, 2017). The idea that competitiveness is intrinsic to sustainable tourism ignores the fact that open markets and liberal trade regimes enables mobile transnational capital to seek absolute advantage, benefitting global investors and corporations at the expense of domestic enterprise and indebted states in the Global South. The superior bargaining power of the former enables them to weaken the regulatory environment or acquire lucrative assets at a favourable price. This is particularly so where debt restructuring has impoverished national governments as in the case of the sale of state-owned Hotel Montelimar to the Barceló group in Nicaragua (Buades 2009, pp. 69-72).

The emphasis on inclusiveness also implies a democratic and participatory approach to economic development. However, the UNWTO merely urges tourism companies to “encourage multi-stakeholder initiatives" (UNWTO, 2016, p.39). Despite calls for the active participation of civil society "partners" alongside other stakeholders in formulating SDGframed policy for tourism, it is telling that the UNWTO sees the role of civil society as one of largely supporting and encouraging the private sector to incorporate sustainability in their business models (UNWTO, 2017a, p.19). The prioritization of corporate interests is further reinforced in the Framework Convention which encourages the development of partnerships between enterprises of generating and receiving countries and corporate support "the equitable distribution of the benefits of its growth" rather than address the complex relationship between tourism growth and poverty itself (UNWTO, 2017b: Art 12.6: 9). There is no discussion of the considerable constraints to such equity imposed by a coercive rulesbased international trade regime nor critical scrutiny of how unequal economic relations are 
produced and reproduced throughout the world trade system and global corporate commodity chains.

The concept of inclusive growth also betrays limited scope of ambitions regarding the role of labour and decent work within a sustainable (tourism) economy. The horizons of decent work are limited to being "inclusive of the large part of the country's labor force" and "productive employment rather than income redistribution" (World Bank, 2009, p.4). This ignores the fact that low wages are significantly determined by the weak bargaining power of workers and the concomitant ability of businesses to impose low wages and harsh working conditions on them (Selwyn, 2014). The conceptual invisibility of contested class relations in sustainable tourism are reflected in the praise given for the corporate social responsibility policies of the NH Hotel Group (UNWTO, 2016, p.41), which has been heavily criticized for outsourcing its cleaning operations and redundancies while simultaneously increasing profits by $€ 76 \mathrm{~m}$ between 2014 and 2016 (Burgen, 2017).

Growth serves both as the principal mechanism through which capitalism's continually expands as well as an ideological tool foreclosing demands for redistributive justice by aligning the interests of labouring classes with capital. Indeed, challenges to restrictive environmental measures by developers have often been justified in the name of job creation and economic development. On occasion this has led to clashes between environmentalists and workers as occurred in the Hilton construction project in Malta during the 1990s (Boissevain and Theuma, 1998). However, to interpret such conflicts as simply a trade-off between environmental conservation and economic development ignores how the schism between workers and environmentalists is produced out of unequal processes of capitalist development in which workers' ability to make meaningful choices over their livelihoods are constrained. Furthermore, it is often peasant farmers, fishers, indigenous peoples and workers who bear the brunt of the impact of environmental degradation resulting from urban development and tourism.

\section{Conclusion}

This paper has argued that the UNWTO's SDG agenda, specifically the notions of 'sustained' and 'inclusive' growth intrinsic to SDG 8 , is marked by unresolved tensions between sustainable development and sustainable tourism. The analysis and critique presented here contends that the principles of 'inclusive growth' and 'decent work' espoused 
by the UNWTO do little to address the contradictions and tensions inherent in the logics of growth and processes of capital accumulation that drive the growth and expansion of tourism. In its belief that sustainability can be reconciled with a growth-led 'inclusive' market capitalism, the UNWTO's proposed revisions to SDG 8 and its broader sustainability agenda remain blind to the injustices that are intrinsic to the systemic processes of exploitation characteristic of tourism capitalism. The horizons of inclusiveness envisaged in their agenda is reliant upon the market to deliver wealth redistribution through sustainable growth. This leaves unaddressed the question of widening and deepening the democratic and cooperative ownership, control and use of productive assets, including in the workplace itself, and the potential for fomenting diverse arrangements of tourism production, thus naturalizing capitalist property relations and inequalities in the distribution of resources. Moreover, there is little to indicate that the UNWTO's SDG agenda has begun to grapple with the increasingly predatory modes of profit extraction and class struggles that characterise emergent variants of authoritarian statist capitalism and its role in driving tourism growth in emerging economies.

The paper has also highlighted the UNWTO's role in marginalising discordant voices from civil society in the process of shaping and subsequently leading the global sustainable tourism agenda that culminated in its current SDG-led agenda. Despite the involvement of civil society in the UNCSD-7 the UNWTO has consistently failed to create an institutional framework that would advance the democratic participation of disempowered groups in ways that not only foster dialogue but would also enable such groups to exert influence on the policies and strategic direction of the institution. By promoting the idea that the interests of corporations can be balanced with workers and local communities without addressing the forces sustaining existing corporate ownership structures and the class dynamics of capital accumulation that drives endless growth, the UNWTO's SDG agenda promises to do little more than reinforce existing hierarchies of political-economic power. In this regard, the authors have highlighted the limited ambitions of decent work as construed by the UNWTO's SDG-agenda. To date, the UNWTO has yet to devise more convincing and robust indicators for such a critical element of sustainable tourism. In so doing the UNWTO remains conceptually blind to the exploitative relations of capitalist development that produce and sustain indecent work in tourism.

The ability of workers to negotiate decent working conditions is furthermore seen as something to be delivered by a benevolent state and/or humane employers. Workers are regarded as a factor of production and/or one amongst many interest groups whose demands 
are to be set alongside those of states, corporations and entrepreneurs whose superior power and ability to shape the organization of production is rarely addressed. This shifts the focus away from the exploitation of labour and expropriation of the commons in the pursuit of profit and the constellations of class power that drive the growth of tourism. Tourism degrowth advocates (Higgins-Desbiolles et al., 2019; Hall, 2009), rightly emphasise the need to reconcile degrowth strategies with fairness, equity and justice to avoid the trap of elitist environmentalism that marginalises the poor and labouring classes. Accordingly, tourism degrowth strategies need to be coupled with a class-relational conception of justice and radical redistribution of power and wealth (not merely a critique of neoliberalism) that involves a more robust interrogation of the industrial organisation and processes of capital accumulation that drive the growth of tourism.

Language and verbal imagery too (note the compelling visual logos for the SDGs) exercise a profound influence on human cognitive understanding, particularly in the realm of abstract economic ideas (Raworth, 2018). Through its prolific use of such adjectives as 'sustained', 'inclusive' and 'decent' to qualify its fully-fledged drive for continual growth the UNWTO's SDG-led agenda is not only misguided but dangerous. Discourses of inclusive growth and decent work shape the distinctive grammar and communicative logics through which markets and growth are normalized in the UNWTO's SDG agenda. This of course is no accident and can perhaps also be interpreted as a political attempt by the UNWTO to steer the dialogue on sustainability away from the questions of environmental and social justice in tourism that would necessitate a radical reorganization of the political and economic structures that drive and sustain the growth-led dynamics of tourism capital accumulation. Further to the critique presented here of the market orthodoxy that frames institutional discourses of 'decent work' and its application to the UNWTO's sustainable tourism agenda, there is scope for closer inspection of the diverse cultural understandings of decent work that may be excluded from such discourses. However, recognition of the diverse social contexts and cultural differences that shape tourism labour markets must not come at the expense of affirming the universal struggle of tourism workers and destination communities to defend their well-being and live free from exploitation. 


\section{Bibliography}

Adler, P. A. \& Adler, P. (2004). Paradise laborers: Hotel work in the global economy. Ithaca and London: Cornell University Press.

Alam, M. S. \& Paramati, S. R. (2016). The impact of tourism on income inequality in developing economies: Does Kuznets curve hypothesis exist? Annals of Tourism Research, 61 (November), 111-126.

Banarjee, B. (2003). Who sustains whose development? Sustainable development and the reinvention of nature. Organization Studies, 24(1), 143-180.

Baum, T. et al. (2016). Sustainability and the tourism and hospitality workforce: A thematic analysis. Sustainability, 8(809). doi:10.3390/su8080809

Bianchi, R. V. (2018). The political economy of tourism development: A critical review. Annals of Tourism Research. 70 (May), 88-102.

Blázquez, M., A. A. Artigues Bonet \& Yrigoy Cadena, I. (2015). Crisis y planificación territorial turística en las Islas Baleares. Investigaciones Turísticas, 9, 24-49.

Boissevain, J. \& Theuma, N. (1998). Contested space: Planners, tourists and environmentalists in Malta. In S. Abram \& Waldren, J. (Eds.), Anthropological Perspectives on Local Development (pp. 96-119). London: Routledge.

Bramwell, B. (2011). Governance, the state and sustainable tourism: a political economy approach. Journal of Sustainable Tourism, 19(4-5), 459-477.

Bramwell, B. (2015). Theoretical activity in sustainable tourism research. Annals of Tourism Research, 54 (September), 204-218.

Bramwell, B. \& Lane, B. (1993). Sustainable tourism: an evolving global approach. Journal of Sustainable Tourism, 1(1), 1-5.

Briassoulis, H. (2002). Sustainable tourism and the commons. Annals of Tourism Research, 29(4), 1065-1085.

Britton, S. G. (1980). The evolution of a colonial-space economy: the case of Fiji. Journal of Historical Geography, 6(3), 251-274.

Britton, S.G. (1991). Tourism, capital, and place: towards a critical geography of tourism. Environment and Planning D: Society and Space, 9(4), 451-478.

Buades, J. (2009). Do not disturb Barceló. Barcelona: Icaria

Burgen, S. (2017). Chambermaids' revolt aims to shame Spain's rogue employers. The Guardian, 15 July, Retrieved 3 September 2019, from https://www.theguardian.com/travel/2017/jul/15/spanish-hotel-cleaners-fightbackexploitation.

Burnham, P. (1994). Open Marxism and vulgar political economy. Review of International Political Economy, 1(2): 221-231. 
Büscher, B. \& Fletcher, R. (2017). Destructive creation: capital accumulation and the structural violence of tourism, Journal of Sustainable Tourism, 25 (5), 651-667.

Cañada, E. (2014). Los que limpian los hoteles. El País, 30 July, Retrieved 20 July 2018, from https://elpais.com/elpais/2014/07/30/alterconsumismo/1406706574 140670.html.

Cave, J. \& Dredge, D. (2018) Reworking tourism: diverse economies and in a changing world. Tourism Planning and Development, 15(5), 473-477.

Chibber, V. (2103). Postcolonial Theory and the specter of capital. London and New York: Verso.

Chin, C. (2008). Cruising in the Global Economy: Profits, Pleasure, and Work at Sea. Farnham: Ashgate.

Christian, M. (2016). Tourism global production networks and uneven social upgrading in Kenya and Uganda. Tourism Geographies, 18(1), 38-58.

Chok, S. (2009). Mega development projects and labour supply chains: whose responsibility is it? CSR Asia Weekly. 5(1), 4-5.

Clancy, M. (2001). Exporting paradise: tourism and development in Mexico. Oxford: Elsevier.

Cole, S. (2012). A political ecology of water equity and tourism: A case study from Bali. Annals of Tourism Research, 39(2), 1221-1241.

CSD (1999a). Tourism and sustainable development: A non-governmental organizational perspective. Background Paper No. 4. UNCSD NGO Steering Committee, Seventh Session of the Commission on Sustainable Development, New York, 19-30 April, United Nations Department of Economic and Social Affairs. Retrieved 14 December 2018, from https://sustainabledevelopment.un.org/content/documents/398wttc.pdf.

CSD (1999b). Tourism and sustainable development: The global importance of tourism. Background Paper No. 1, World Travel and Tourism Council and International Hotel and Restaurant Association, Seventh Session of the Commission on Sustainable Development, New York, 19-30 April, United Nations Department of Economic and Social Affairs. Retrieved from https://sustainabledevelopment.un.org/content/documents/398wttc.pdf.(14 December, 2018).

CSD (1999c). Tourism and sustainable development: Workers and trade unions in the web of tourism. Background Paper No. 2, International Confederation of Free Trade Unions and Trade Union Advisory Committee to the OECD, Seventh Session of the Commission on Sustainable Development, New York, 19-30 April, United Nations Department of Economic and Social Affairs. Retrieved 14 December 2019, from https://sustainabledevelopment.un.org/content/documents/398wttc.pdf.

Crick, M. (1995). Resplendent sites, discordant voices: Sri Lankans and international tourism. Chur: Harwood Academic Publishers.

Coria, J. \& E. Calfucura (2012). Ecotourism and the development of indigenous communities: The good, the bad, and the ugly. Ecological Economics, 73, 47-55. 
Davies, W. (2016). The new neoliberalism. New Left Review, 121, 121-134.

De Angelis, M. (2007) The beginning of history: Value struggles and global capital. London and Ann Arbor, MI: Pluto Press.

Devine, J. A. (2017). Colonizing space and commodifying place: tourism's violent geographies. Journal of Sustainable Tourism, 25(5), 634-650.

Dodds, F. (2019). Stakeholder democracy: Represented democracy in a time of fear. London and New York: Routledge.

Douthwaite, R. (1999). Is it possible to build a sustainable world? In R. Munck \& D. O'Hearn (Eds.), Critical Development Theory: Contributions to a New Paradigm (pp. 157177). London: Zed Books.

Dredge, D. \& Gyimóthy, S. (2015). The collaborative economy and tourism: Critical perspectives, questionable claims and silenced voices. Tourism Recreation Research, 40(3), 286-302.

Dredge, D. \& Jamal, T. (2013). Mobilities on the Gold Coast, Australia: Implications for destination governance and sustainable tourism. Journal of Sustainable Tourism, 21(4), 557579.

Duffy, R. (2015). Nature-based tourism and neoliberalism: concealing contradictions. Tourism Geographies, 17 (4), 529-543.

Epler Wood, M., Milstein, M. \& Ahamed-Broadhurst, K. (2019). Destinations at risk: The invisible burden of tourism. Bristol: The Travel Foundation.

FDI Intelligence (2018). Tourism investment 2018. London: Financial Times.

Ferguson, L. (2007). The United Nations World Tourism Organisation. New Political Economy. 12(4): 557-568.

Fingar, L. (2018). UNWTO secretary general puts employment first. FDI Intelligence, 12 April. Retrieved 18 July 2018, from https://www.fdiintelligence.com/Sectors/HotelsTourism/UNWTO-secretary-general-puts-employment-first.

Fioramonti, L. (2013). Gross domestic problem: The politics behind the world's most powerful number. London: Zed Books.

Fletcher, R. (2011). Sustaining tourism, sustaining capitalism? The tourism industry's role in global capitalist expansion. Tourism Geographies 13(3), 443-461.

Gascón, J. (2019). Tourism as a right: "frivolous claim" against degrowth? Journal of Sustainable Tourism, 27(12): 1825-1838.

Gibson, C. (2009). Geographies of tourism: Critical research on capitalism and local livelihoods. Progress in Human Geography, 33(4), 527-534.

Gleckman, H. (2016). Multi-stakeholder governance: a corporate push for a new global governance. Open Democracy, 19 January. Retrieved 10 November 2019, from https://www.opendemocracy.net/en/multi-stakeholder-governance-corporate-push-for-newglobal-governance/. 
Goldman, B. A. (2011). Equity and the 1992 Rio Earth Summit. Fordham Environmental Law Review, 4(1), 1-8.

Gössling, S. \& Hall, C.M. (2019). Sharing versus collaborative economy: how to align ICT development and the SDGs in tourism? Journal of Sustainable Tourism, 27(1), 74-96.

Grossman, P. and Greenfield, G. (2006). Financialization: New Routes to Profit, New Challenges for Trade Unions. Labour Education, The Quarterly Review of the ILO Bureau for Workers' Activities, 1/2006, No. 142. Retrieved 20 June 2016, from http://www.iufdocuments.org/www/documents/Financialization-e.pdf.

Hall, C. M. (2009). Degrowing tourism: Décroissance, sustainable consumption and steady-state tourism. Anatolia, 20(1), 46-61.

Hall, C. M. (2019). Constructing sustainable tourism development: the 2030 agenda and the managerial ecology of sustainable tourism. Journal of Sustainable Tourism, 27(7), 10441060 .

Hampton, M. P. (2010). Enclaves and ethnic ties: The local impacts of Singaporean crossborder tourism in Malaysia and Indonesia. Singapore Journal of Tropical Geography, 31, 239-253.

Hampton, M. P., J. Jeyacheya and Pham Hong Long (2018). Can tourism promote inclusive growth? Supply chains, ownership and employment in Ha Long Bay, Vietnam. Journal of Development Studies, 54(2), 359-76.

Hampton, M. P., J. Jeyacheya \& Lee, D. (2018). The political economy of dive tourism: precarity at the periphery in Malaysia. Tourism Geographies, 20(1), 107-26.

Hickel, J. (2017). The divide: A brief guide to global inequality and its solutions. London: William Heinemann.

Hickel, J. (2019a). Degrowth: a theory of radical abundance. Real World Economics Review, 87: 54-68. Retrieved 17 January 2020, from http://www.paecon.net/PAEReview/issue87/Hickel87.pdf

Hickel, J. (2019b). The contradiction of the sustainable development goals: Growth versus ecology on a finite planet. Sustainable Development, 1-12. doi.org/10.1002/sd.1947.

Higgins-Desbiolles, F. (2006). More than an industry: Tourism as a social force. Tourism Management, 27(6): 1192-1208.

Higgins-Desbiolles, F. (2018). Sustaining tourism: Sustaining tourism or something else? Tourism Management Perspectives, 25, 157-160.

Higgins-Desbiolles, F., S. Carnicelli, C. Krolikowski, G. Wijesinghe \& Boluk, K. (2019). Degrowing tourism: rethinking tourism. Journal of Sustainable Tourism, DOI, 10.1080/09669582.2019.1601732.

Hilary, J. (2013). The poverty of capitalism: The economics of meltdown and the struggle for what comes next. London: Pluto Press. 
Hof, A. \& Blázquez-Salom, M. (2015). Changing tourism patterns, capital accumulation, and urban water consumption in Mallorca, Spain: a sustainability fix? Journal of Sustainable Tourism, 23(5), 770-796.

Holden, A. (2003). In need of new environmental ethics for tourism? Annals of Tourism Research, 30(1), 94-108.

Holden, A. (2013). Tourism, poverty and development. London: Routledge.

Hunter, C. (1997). Sustainable tourism as an adaptive paradigm. Annals of Tourism Research, 24(4), 850-867.

ILO (1999). Decent work. Report of the Director-General. Report of the $87^{\text {th }}$ session. Geneva: International Labour Office. Retrieved 11 November 2019, from https://www.ilo.org/public/english/standards/relm/ilc/ilc87/reports.htm.

ILO (2010). Developments and challenges in the hospitality and tourism sector. Geneva: International Labour Office.

ILO (2012). Migrant workers in the international hotel industry. International Migration Paper No. 112. Geneva: International Labour Office.

ILO (2017). ILO Guidelines on decent work and socially responsible tourism. Geneva: International Labour Office.

Jamal, T. (2019). Justice and ethics in tourism. London and New York: Routledge.

Jamal T. \& Camargo, B. (2014). Sustainable tourism, justice and an ethic of care: toward the Just Destination. Journal of Sustainable Tourism, 22(1), 11-30.

Keller, P. \& Bieger, T. (Eds.) (2011). Introduction. In Keller, P. \& Bieger, T. (Eds.), Tourism Development after the Crises Global Imbalances - Poverty Alleviation. (pp. 1-25). Berlin: Erich-Schmidt Verlag.

Klein, N. (2014). This changes everything: Capitalism vs the climate. Penguin.

Ladkin, A. (2011). Exploring tourism labor. Annals of Tourism Research, 38 (3), 1135 1155 .

Lee, D. M. Hampton \& Jeyacheya, J. (2015). The political economy of precarious work in the tourism industry in small islands states. Review of International Political Economy, 22(1), 194-223.

Lenzen, M., Y-Y. Sun, F. Faturay, Y-P. Ting, A. Geschke \& Malik, A. (2018). The carbon footprint of global tourism. Nature Climate Change. 8, 522-528.

McCool, S. F., N. Moisey, N. P. Nickerson (2001). What should tourism sustain? The disconnect with industry perceptions of useful indicators. Journal of Travel Research, 40(2), $124-131$.

Madsen Camacho, M. E. (1996). Dissenting workers and social control: A case study of the hotel industry in Huatulco, Oaxaca. Human Organization, 55(1), 33-40.

Marx, K. (1973). Grundrisse. Harmondsworth: Penguin. 
Marx, K. (1974). Capital: A critical analysis of capitalist production. Volume 1. London: Lawrence and Wishart.

Marx, K. (1977). The German Ideology. In D. McLellan (Ed.), Karl Marx: Selected writings (pp. 159-191). Oxford: Oxford University Press.

Mas, I., I. Yrigoy Cadena \& Blázquez-Salom, M. (2017). The role of crises in the production, destruction and restructuring of tourist spaces. The case of the Balearic Islands. Investigaciones Turísticas, 13, 1-29.

Mitchell, J. (2017). Tourism's green gold rush. FDI Intelligence, 14 December. Retrieved 14 August 2019, from https://www.fdiintelligence.com/Sectors/Hotels-Tourism/Tourism-sgreen-gold-rush.

Mittal, A. and E. Fraser (2018). Losing the Serengeti: the Maasai land that was to run forever. Oakland, CA: The Oakland Institute.

Mosedale, J. (2006). Tourism commodity chains: market entry and their effects on St. Lucia. Current Issues in Tourism, 9 (4/5), 436-458.

Neto, F. (2003). A New approach to sustainable tourism development: Moving beyond environmental protection. DESA Discussion Paper 29. New York: United Nations.

Peters, M. (1969). International Tourism: The Economics and Development of the International Tourist Trade. London: Hutchinson.

PwC (2018). Global top 100 companies by market capitalisation. London: Price Waterhouse Cooper. IPO publications.

Raworth, K. (2018). Doughnut economics: Seven ways to think like a $21^{\text {st }}$ century economist. London: Random House.

Reid, D. G. (2003). Tourism, globalization and development: Responsible tourism Planning. London: Pluto Press.

Rifai, T. (2017). Tourism: growth is not the enemy; it's how we manage it that counts. UNWTO Press Release. August 15. Retrieved 14 December, from http://media.unwto.org/press-release/2017-08-15/tourism-growth-not-enemy-it-s-how-wemanage-it-counts.

Saad-Filho, A. (2010). Growth, poverty and inequality: From Washington Consensus to inclusive growth. UN/DESA Working Paper 100. November. New York: United Nations Department of Economic and Social Affairs.

Saarinen, J. (2006). Traditions of sustainability in tourism studies. Annals of Tourism Research, 33(4), 1121-1140.

Saarinen, J. (2018). Beyond growth thinking: the need to revisit sustainable development in tourism, Tourism Geographies, 20(2), 337-340.

Sala, E. (2011). Ocean ecosystem services can increase - But only if we take less. National Geographic, 5 April. Retrieved from 
https://blog.nationalgeographic.org/2011/04/05/ocean-ecosystem-services-can-increase-butonly-if-we-take-less/. (12 September, 2018)

Scheyvens, R. (1999). Ecotourism and the empowerment of communities. Tourism Management, 20(2): 245-249.

Scheyvens, R. (2007). Exploring the tourism-poverty nexus. Current Issues in Tourism, $10(2 \& 3), 231-254$.

Scheyvens, R. \& Biddulph, R. (2017). Inclusive tourism development. Journal of Sustainable Development, 20(4), 589-609.

Schilcher, D. (2007). Growth versus equity: The continuum of pro-poor tourism and neoliberal governance. Current Issues in Tourism, 10(2\&3), 166-193.

Selwyn, B. (2014). How to achieve decent work? Global Labour Column, No. 161, January.

Selwyn, B. (2015). Twenty-first century International political economy: A classrelational perspective. European Journal of International Relations, 21(3), 513-537.

Sharpley, R. (2015). Tourism: a vehicle for development? In R. Sharpley \& Telfer, D. J. (Eds.) Tourism and Development: Concepts and Issues (pp. 3-30). Clevedon: Channel View.

Sheikh, A. (2010). Outsourcing of employers' responsibility in the false name of flexibility. Employee Relations, 32(5), 495-508.

Shivji, I. (1973). Tourism and socialist development. Dar es Salaam: Tanzania Publishing House.

Steiner, C. (2006). Tourism, poverty reduction and the political economy: Egyptian perspectives on tourism's economic benefits in a semi-rentier state. Tourism and Hospitality Planning and Development 3(3), 161-177.

Streeck, W. (2014). Buying time: The delayed crisis of democratic capitalism. London and New York: Verso.

Stroebel, M. (2015). Tourism and the green economy: inspiring or averting change? Third World Quarterly, 36,12, 2225-2243.

Tao, T. C. H. \& Wall, G. (2009). Tourism as a sustainable livelihood strategy. Tourism Management, 30(1): 90-98.

Teberga De Paula, A. (2018). Un panorama sobre la precarización del trabajo turístico en Brasil. Alba Sud, 23 June. Retrieved 23 July 2018, from http://www.albasud.org/noticia/es/1039/un-panorama-sobre-la-precarizaci-n-del-trabajo-turstico-en-brasil.

UN (1992). Agenda 21. United Nations Conference on Environment \& Development. Rio de Janerio, Brazil, 3-14 June 1992. Retrieved 23 October 2019, from https://sustainabledevelopment.un.org/content/documents/Agenda21.pdf. 
UN (2000). United Nations millennium declaration. Resolution adopted by the UN General Assembly, 55/2. Retrieved 21 September 2018, from http://www.un.org/millennium/declaration/ares552e.htm.

UN (2015). Transforming our world: the 2030 agenda for sustainable development. New York: Resolution adopted by the General Assembly on 25 September 2015. Retrieved 21 September 2018, from https://sustainabledevelopment.un.org/post2015/transformingourworld.

UN News (2011). Tourism an important force to reduce poverty and foster global solidarity - UN. Retrieved 10 September 2018, from https://news.un.org/en/story/2011/09/389282-tourism-important-force-reduce-poverty-andfoster-global-solidarity-un.

UNCTAD (1973). Elements of tourism policy for developing countries. New York: United Nations Publications TD/B/C.3/89/Rev.1

UNCTAD (2010). The contribution of tourism to trade and development. 3-7 May 2010. Geneva: United Nations Conference on Trade and Development.

UNEP \& UNWTO (2012). Tourism in the green economy - Background report. Madrid. UNWTO

UNWTO (2016). The tourism sector and the sustainable development goals. Madrid: UNWTO

UNWTO (2017a). Tourism and the sustainable development goals - Journey to 2030. Madrid: UN World Tourism Organisation.

UNWTO (2017b). Framework convention on ethics. Madrid: UN World Tourism Organisation. Retrieved 20 September, from http://cf.cdn.unwto.org/sites/all/files/docpdf/ares707xxiiconventionontourismethics.pdf.

UNWTO (2017c). Chengdu Declaration on Tourism and the Sustainable Development Goals. General Assembly, 22 ${ }^{\text {nd }}$ session, Chengdu, China, 11-16 September. Retrieved 11 November, from http://cf.cdn.unwto.org/sites/all/files/pdf/13.09.17 unwto ga22hl chengdu declaration final clean .pdf.

UNWTO (2018a). Contribution from the countries in the Committee on Tourism Statistics and Tourism Satellite Account of the UN WTO (UNWTO). Seventh Meeting of the InterAgency and Expert Group on the Sustainable Development Goal Indicators. 10-12 April, Vienna: Austria.

UNWTO (2018b). Tourism for development - volume I: Key areas for action. Madrid: United Nations World Tourism Organisation.

UNWTO (2019). International tourist arrivals reach 1.4 billion two years ahead of forecasts. PR19003, 21 January. Madrid: United Nations World Tourism Organisation Retrieved 13 August, from https://www2.unwto.org/press-release/2019-01-21/internationaltourist-arrivals-reach-14-billion-two-years-ahead-forecasts. 
WCED (1987). Our common future. World Commission on Environment and Development. Oxford: Oxford University Press.

Winchenbach, A., P. Hanna \& Miller, G. (2019). Rethinking decent work: the value of dignity in tourism employment. Journal of Sustainable Tourism, 27(7), 1026-1043.

Wolf, E. (1982). Europe and the people without history. Berkeley, CA: University of California Press.

Wood, E. M. (2016). Democracy against capitalism: Renewing historical materialism. London and New York: Verso.

Woodward, D. (2015). Incrementum ad absurdum: Global growth, inequality and poverty eradication in a carbon-constrained world. World Economic Review, 4, 43-62.

World Bank (2009). What is inclusive growth? World Bank Note 10. Retrieved 10 September 2018, from

http://siteresources.worldbank.org/INTDEBTDEPT/Resources/4689801218567884549/WhatIsInclusiveGrowth20081230.pdf.

WTO (1980). Manila Declaration on World Tourism. Madrid: World Tourism Organisation. Retrieved 14 November, from https://www.eunwto.org/doi/pdf/10.18111/unwtodeclarations.1980.01.01.

WTO (1982). Acapulco Document. Madrid: World Tourism Organisation. Retrieved 14 November, from https://www.e-unwto.org/doi/abs/10.18111/unwtodeclarations. 1982.02.01.

WTO (1999a). Tourism and sustainable development. Seventh Session of the Commission on Sustainable Development, New York, 19-30 April 1999, United Nations Department of Economic and Social Affairs. Retrieved 20 September 2019, from https://www.un.org/ga/search/view_doc.asp?symbol=E/CN.17/1999/5/Add.1\&Lang=E.

WTO (1999b). Global code of ethics for tourism. Madrid: Word Tourism Organisation. Retrieved 14 September 2018, from http://www.unwto.org/ethics/index.php.

WTTC (2017). Coping with success: Managing overcrowding in tourism destinations. London: McKinsey \& Company and WTTC.

WTTC (2018). Travel and tourism: Economic impact 2018. London: World Travel and Tourism Council.

Yrigoy, I. (2016). Financialization of hotel corporations in Spain. Tourism Geographies, $18(4), 399-421$.

\footnotetext{
${ }^{11}$ Raoul Bianchi is a Reader in International Tourism and Development in the School of Business and Law, University of East London. His work is focused on the politics and international political economy of tourism with a particular interest in coastal tourism development in Spain and the Mediterranean region. He has also been involved in campaigning on tourism and human rights, fair trade and sustainability and was on the steering group of UK NGO Tourism Concern from 1997-2003.
} 
Frans de Man is an advisor for tourism and sustainable development and director of the Retour Foundation from 1987-2019. He played an important role in the Tourism European Network (TEN) from 1984-2015 and in the Transforming Tourism Initiative from 2016-2019. From 1999-2002 he was the northern co-chair of the global UNCSD NGO Tourism Caucus.

${ }^{2}$ The analysis draws on recent UNWTO reports on the SDGs while also identifying important discursive and ideological continuities with other key reports approved by the General Assembly of the UNWTO such as the UNWTO Global Code of Ethics (WTO, 1999b) and its successor the Framework Convention on Tourism Ethics (UNWTO 2017b). It is important to note that these documents do not always reflect the official position of the UNWTO.

${ }^{3}$ Recent calculations suggest that international tourism accounts for 8 per cent of global GHG emissions (Lenzen et al., 2018).

${ }^{4}$ SDG1 uses the standard international benchmark for 'extreme poverty' of US\$1.25. Even if the logics of growth-driven market capitalism are accepted Woodward (2015) contends that to eradicate global poverty (at US $\$ 1.25$ per day) would take at least 100 years at a rate of 2.35 per cent per capita growth.

${ }^{5}$ Simon Kuznets, the economist who devised GDP metrics in the 1930s, later to sought to exclude the gains from speculative financial transactions from national income (Fioramonti, 2014: 57-8).

${ }^{6}$ There are few major tourism, hospitality and resort corporations amongst the world's top 100 corporations. An exception is Booking Holdings, the world's largest on-line travel retailer whose market value (US\$93bn) increased by a remarkable 3,233 percent between 2009 and 2015 (PwC, 2018).

${ }^{7}$ US industrial interests rejected any reference to 'sustainability' at the 1972 UN Conference on the Human Environment held in Stockholm (Fioramonti, 2013, p.84).

${ }^{8}$ The WTTC is a global coalition of corporate executives formed in London in 1990 representing 170 of the world's largest tourism and hospitality companies.

${ }^{9}$ ICLEI is a global network of $1,500+$ cities, towns and regions committed to building a sustainable future.

${ }^{10}$ The five major goals are: to end poverty and hunger everywhere; to combat inequalities within and among countries; to build peaceful, just and inclusive societies; to protect human rights and promote gender equality and the empowerment of women and girls; to ensure the lasting protection of the planet and its natural resources. 